\title{
Genetic Polymorphisms of Cytokines Might Affect Postoperative Sufentanil Dosage for Analgesia in Patients
}

\author{
Jian Guo $\mathbb{D}^{1,2, *}$ \\ Fei Yuan ${ }^{3, *}$ \\ Yixin Yang' \\ Yunze $\mathrm{Li}^{1}$ \\ Fangping $\mathrm{Bao}\left(\mathbb{D}^{2}\right.$ \\ Xuejiao Guo' \\ Zhiying Feng (D'
}

'Department of Pain Medicine, The First Affiliated Hospital, Zhejiang University, School of Medicine, Hangzhou, Zhejiang 3 I0003, People's Republic of China;

${ }^{2}$ Department of Anesthesiology, The Fourth Affiliated Hospital, Zhejiang University, School of Medicine, Yiwu, Zhejiang 322000, People's Republic of China; ${ }^{3}$ Department of Anesthesiology, Shaoxing Second Hospital, Shaoxing, Zhejiang 312000, People's Republic of China

*These authors contributed equally to this work
This article was published in the following Dove Press journal: Journal of Pain Research

Objective: To explore the effect of genetic polymorphisms of cytokines on the dosage of sufentanil for patient-controlled intravenous analgesia (PCIA) after radical lung cancer surgery.

Methods: A total of 100 patients, aged 18 years and above, with ASA grade I - II and body mass index (BMI) 18.5 to 30, and who were scheduled for radical lung cancer surgery under total intravenous anaesthesia with PCIA of sufentanil from September 2015 to March 2016, were selected. DNA was collected from peripheral blood samples before surgery, and the iMLDRTM multiple single-nucleotide polymorphism typing kit was used to detect 16 related single-nucleotide polymorphism (SNP) sites of interleukin-1A (IL-1A), interleukin-1 $\beta$ (IL-1 $\beta$ ), interleukin-1RN (IL-1RN), interleukin-6 (IL-6), C-X-C motif chemokine ligand 8 (CXCL8), interleukin-10 (IL-10), tumour necrosis factor (TNF), nuclear factor kappa-B1 (NFאB1), REL (REL protooncogene, NF-kB subunit), and nuclear factor kappa-B inhibitor alpha (NFkBIA). The general characteristics of patients, surgery and anaesthesia data, postoperative resting VAS pain scores, postoperative opioid dosages of sufentanil for PCIA and opioid-related adverse events were recorded. The effects of the examined genetic polymorphisms of the cytokines on the dosage of sufentanil were analysed.

Results: Eight of 100 patients withdrew for various reasons, and, eventually, 92 patients were included. The patients' resting visual analogue scale (VAS) scores at $24 \mathrm{~h}, 48 \mathrm{~h}$, and $72 \mathrm{~h}$ after surgery were $2.3 \pm 1.2,2.0 \pm 0.9$, and $1.9 \pm 1.0$, respectively. The total amounts of sufentanil used were $34.7 \pm 10.5 \mu \mathrm{g}, 65.2 \pm 13.7 \mu \mathrm{g}$, and $94.7 \pm 11.6 \mu \mathrm{g}$, respectively. We found that the TT genotype of NFkBIA rs696 had higher PCIA sufentanil dosages than the $\mathrm{CC}$ genotype and the CT genotype at $48-72 \mathrm{~h}$ postoperation $(\mathrm{p}=0.023, \mathrm{p}=0.025$, respectively).

Conclusion: The genetic polymorphisms of the cytokine NFkBIA rs696 might affect the dosage of sufentanil for PCIA after radical lung cancer surgery. The specific mechanism needs further study.

Keywords: genetic polymorphisms, single-nucleotide polymorphism, SNP, patientcontrolled intravenous analgesia, PCIA, nuclear factor kappa-B inhibitor alpha, NFкBIA

\section{Background}

How to effectively alleviate postoperative pain to accelerate patients' recovery after surgery, especially after thoracic surgery, remains a medical challenge today. ${ }^{1,2}$ These patients may endure severe postoperative acute pain due to skin and deep soft tissue damage, rib or sternal fractures, lung tissue damage and the placement of closed drainage tubes in the thoracic cavity. Poorly controlled acute postoperative
Correspondence: Zhiying Feng Email fzy1972@zju.edu.cn
Journal of Pain Research 2020:13 |46|-|470

|46 | 
pain during the first 3 days after surgery correlates with persistent chronic post-thoracotomy pain at 6 months, which can develop to chronic pain syndrome. ${ }^{3}$

Currently, a multimodal analgesia approach consisting of non-steroidal anti-inflammatory analgesics, nerve blocks and opioids during perioperative analgesia of thoracic surgery has been highly recommended and adopted. ${ }^{4}$ The application of opioids using patient-controlled intravenous analgesia (PCIA) technology is one of the main analgesic methods after thoracic surgery. ${ }^{5}$ Sufentanil is widely used in postoperative analgesia because of its strong analgesic effects, insignificant accumulation, rapid clearance, minor effects on circulation, weak respiratory depression and low incidence of nausea and vomiting. ${ }^{6-8}$

In postoperative multimodal analgesia, opioids remain the cornerstone. An insufficient dosage of opioids may lead to a poor analgesic effect, which will then inevitably affect patients' recovery after surgery. An overdose of opioids will lead to serious adverse reactions such as excessive sedation and respiratory depression. Therefore, individualized therapy of opioids for postoperative analgesia is the key point for patients' safety while promoting patients' Enhanced Recovery After Surgery (ERAS).

However, the dosage of opioids shows significant differences amongst individuals in PCIA. In the past, these differences were attributed to related factors such as patient's age, gender, weight, surgical trauma, and anaesthesia. In recent years, many studies have confirmed that genetic factors such as single-nucleotide polymorphisms (SNPs) do have great impact on postoperative analgesia, especially on the absorption, transport, metabolism, elimination and efficacy of opioids. $^{9-18}$ Lee et al, ${ }^{12}$ found that a genetic polymorphism at the $\mu$-opioid receptor gene (OPRM1) A118G influenced the analgesic effect of morphine for immediate acute postoperative pain in children. Zhang et al, ${ }^{17}$ found that catecholO-methyl transferase (COMT) gene haplotype contributed to the individual variation of postoperative analgesia with fentanyl. Yuan et al, ${ }^{18}$ found that the CYP3A4*1G genetic polymorphism decreases the metabolism of fentanyl in human liver microsomes obtained from Chinese patients. Therefore, are there any other factors that affect the dosage of opioids in genetic polymorphisms?

Thoracic surgery is often accompanied by an increased level of various immune inflammation-related cytokines such as interleukin-6 (IL-6), interleukin-8 (IL-8), and interleukin-10 (IL-10). ${ }^{19}$ Surgery-related stimuli will induce the release of inflammatory cytokines that have immunoregulatory functions or inflammatory or anti- inflammatory effects. Different dosages of opioids are needed for postoperative pain, which is closely related to the release of cytokines or inflammatory factors such as interleukin (IL), tumour necrosis factor-alpha (TNF- $\alpha$ ), etc. $^{20-22}$ Cytokines modulate nociceptive signalling during acute inflammation and following tissue injury, and they may cause significant inter-individual variability in postoperative pain (including development, intensity, and resolution of pain). ${ }^{23,24}$ Central cytokines and chemokines are powerful neuromodulators and play a significant role in inducing hyperalgesia and allodynia after central nervous system administration, and they drive widespread chronic pain via central sensitization. ${ }^{25}$ We speculate that the genetic polymorphisms of cytokines related to perioperative immune inflammation may affect the postoperative PCIA sufentanil dosage. For this reason, this study intends to explore the effect of genetic polymorphisms of cytokines on the dosage of PCIA sufentanil after radical lung cancer surgery to provide a theoretical basis for the development of an individual PCIA sufentanil scheme.

\section{Objects and Methods Research Objects}

The study was conducted in accordance with the Declaration of Helsinki, and that the patient consent was written informed consent. The trial has been approved by the Ethics Committee of the First Affiliated Hospital Zhejiang University School of Medicine (2015 [254]), and consents were obtained from patients and their families.

\section{Inclusion Criteria}

100 patients who were diagnosed with lung cancer in the hospital from September 2015 to March 2016, were selected and received radical lung cancer surgery under total intravenous anaesthesia. They were aged $\geq 18$ years with no gender restriction and had ASA grade I - II and BMI 18.5-30.

\section{Exclusion Criteria}

Patients who were unable to be treated under parecoxib sodium for postoperative analgesia for various reasons, with severe neurological and psychiatric disorders, who were on non-steroidal or opioid analgesics for a long time, or who had a total Hamilton Anxiety Scale score $\geq 7$ points or Hamilton Depression Scale $\geq 8$ points. 


\section{Methods}

\section{Anaesthesia and Analgesia}

Patients were routinely monitored for ECG, blood pressure, and oxygen saturation after entering the operating room. Invasive arterial pressure monitoring was done in the radial artery of the non-operative side of the lung. Total intravenous anaesthesia was induced with $0.05 \mathrm{mg} / \mathrm{kg}$ midazolam, $2 \mathrm{mg} / \mathrm{kg}$ propofol, $0.6 \mathrm{mg} / \mathrm{kg}$ rocuronium and $0.3 \mu \mathrm{g} / \mathrm{kg}$ sufentanil. A double-lumen endotracheal tube (males \#37-39, females \#32-35, where the appropriate double tracheal model was selected based on the CT measurement of the tracheal diameter) was inserted 5 mins later. A fibreoptic bronchoscope was used to confirm the location of the tube. An $8 \mathrm{~mL} / \mathrm{kg}$ tidal volume (VT), $60 \%$ fraction of $\mathrm{O}_{2}$ inspiration $\left(\mathrm{FiO}_{2}\right)$, and respiratory rate (RR) of 12 times/min were used for double lung ventilation, adjusting the $R R$ exhalation to maintain $\mathrm{PaCO}_{2}$ at $35-45 \mathrm{mmHg}$.

A protective ventilation strategy was used for single lung ventilation with a VT of $6 \mathrm{~mL} / \mathrm{kg}, \mathrm{FiO}_{2}$ of $60-100 \%$ (as low as possible), RR at $12-16$ times/min, positive endexpiratory pressure ventilation $\left(5 \mathrm{~cm} \mathrm{H}_{2} \mathrm{O}\right)$ and intermittent lung dilatation to maintain a $\mathrm{PaCO}_{2}$ of $35-45 \mathrm{mmHg}$. Anaesthesia was maintained with $6 \mathrm{mg} \mathrm{kg}^{-1} \mathrm{~h}^{-1}$ propofol, $0.05 \mu \mathrm{g} \mathrm{kg}^{-1} \mathrm{~min}^{-1}$ remifentanil and $0.15 \mathrm{mg} / \mathrm{kg}$ rocuronium (every 40 mins).

Sufentanil $(0.2 \mu \mathrm{g} / \mathrm{kg})$ was intravenously administered 2 minutes before the incision, and the concentrations of remifentanil and propofol were adjusted according to the Bispectral Index (BIS) value and blood pressure. The BIS value was maintained at 40-60, ensuring that the blood pressure fluctuation range did not exceed $\pm 20 \%$ of the base value. Palonosetron hydrochloride at $0.25 \mathrm{mg}$ was injected 30 mins before the end of surgery to prevent postoperative nausea and vomiting. Anaesthesia maintenance medications were discontinued 5 minutes before surgery. All of these operations were performed under a three-hole fullthoracoscopy by the same group of doctors. Patients were transferred to the postanaesthesia care unit (PACU) for anaesthesia resuscitation and extubation after the operation.

Multimodal analgesia was used during the perioperative period. Sufentanil $(0.2 \mu \mathrm{g} / \mathrm{kg})$ was intravenously injected 30 minutes prior to the end of the operation. Parecoxib sodium $(40 \mathrm{mg})$ was intravenously injected before the operation and then twice daily for three consecutive days. When the chest was closed, a $0.50 \%$ ropivacaine $10 \mathrm{~mL}$ incision was used for local infiltration, and
PCIA was used for postoperative analgesia. PCIA (sufentanil, $100 \mu \mathrm{g} / 250 \mathrm{~mL}$ ) was used for $72 \mathrm{~h}$ for postoperative acute pain control. The parameters were set as follows:

- load $5 \mu \mathrm{g}$, background infusion rate of $3 \mu \mathrm{g} / \mathrm{h}$,

- bolus $2 \mu \mathrm{g}$, lock time $10 \mathrm{~min}$, lock dosage of $20 \mu \mathrm{g} / \mathrm{h}$.

When the patient had a VAS score $\geq 4$ points at the ward, a bolus of $2 \mu \mathrm{g}$ Sufentanil was used after the patient pressed once. If the VAS score was still $\geq 4$ points after two consecutive valid pressures, tramadol $100 \mathrm{mg}$ hydrochloride were intramuscularly injected for analgesia. When the patient had a VAS score $\geq 7$ points, Acute Pain Service was also called in to adjust the PCIA parameters to control the patient's VAS score to $\leq 3$ points. PCIA ceased after 3 days and if the VAS score remained $\geq 4$ points, $200 \mathrm{mg}$ celecoxib capsules were given.

The resting VAS pain score and the dosages of sufentanil at $24 \mathrm{~h}, 48 \mathrm{~h}$, and $72 \mathrm{~h}$ after surgery were recorded. Tramadol was converted to equivalent sufentanil (100 mg tramadol are equivalent to $13.3 \mu \mathrm{g}$ sufentanil) ${ }^{26}$ for statistical purposes. Postoperative nausea, vomiting, pruritus, sedation, respiratory depression, hypotension and other related adverse reactions were recorded.

\section{Detection of SNPs}

A total of 16 polymorphisms (SNPs) of cytokines were selected according to a literature search. Table 1 shows the primers that were selected for polymorphism genotyping. After patient entered the room, $2 \mathrm{~mL}$ of venous blood were drawn and injected into an ETDA anticoagulation tube and stored in a refrigerator at $4{ }^{\circ} \mathrm{C}$. Genomic DNA was extracted from the blood using a Maxwell 16 Blood DNA purification kit (Shanghai shengzhao biotechnology co., LTD). The iMLDRTM multiple SNP typing kit (Shanghai shengzhao biotechnology co., LTD) was used to type the SNPs of the samples. ${ }^{27}$ Raw data collected on the sequencer were analysed by GeneMapper 4.0 (Applied Biosystems, USA).

\section{Statistical Methods}

SPSS 19.0 statistical software was used for analytical purposes. The results of the measurement data conforming to a normal distribution are expressed as the means \pm standard deviation $(\overline{\mathrm{x}} \pm \mathrm{sd})$. To test whether alleles and genotypes meet Hardy-Weinberg equilibrium, the $\chi^{2}$ test was used. Data between multiple groups were compared using a single factor analysis of variance (ANOVA). Grade 
Table I Selected Polymorphisms (SNPs)

\begin{tabular}{|c|c|c|c|c|c|}
\hline No. & SNP & Gene & Allele & $\begin{array}{l}\text { Wild- } \\
\text { Type }\end{array}$ & Polymorphic \\
\hline I & rs 17561 & IL-IA & $C>A$ & c & A \\
\hline 2 & rs|800587 & IL-IA & $G>A$ & G & A \\
\hline 3 & rsII43634 & IL-I $\beta$ & $G>A$ & G & A \\
\hline 4 & rs 16944 & IL-I $\beta$ & $A>G$ & A & G \\
\hline 5 & rs419598 & IL-IRN & $\mathrm{T}>\mathrm{C}$ & $\mathrm{T}$ & C \\
\hline 6 & rs|800795 & IL-6 & $C>G$ & C & G \\
\hline 7 & rs4073 & CXCL8 & $A>T$ & A & $\mathrm{T}$ \\
\hline 8 & rs|80087| & IL-10 & $A>G$ & A & G \\
\hline 9 & rs|800872 & IL-10 & $\mathrm{T}>\mathrm{G}$ & $\mathrm{T}$ & G \\
\hline 10 & rs1800896 & IL-10 & $\mathrm{T}>\mathrm{C}$ & $\mathrm{T}$ & C \\
\hline 11 & rs1800629 & TNF & $G>A$ & G & A \\
\hline 12 & rs2836249| & $\mathrm{NF} \kappa \mathrm{BI}$ & delATTG & - & delATTG \\
\hline 13 & rs3774932 & $N F \kappa B I$ & $A>G$ & A & G \\
\hline 14 & rs842647 & REL & $G>A$ & G & A \\
\hline 15 & rs8904 & NF-kBIA & $G>A$ & G & A \\
\hline 16 & rs696 & NF-kBIA & $C>T$ & C & $\mathrm{T}$ \\
\hline
\end{tabular}

count data were tested by $\chi^{2}$. A difference of $\mathrm{P}<0.05$ was statistically significant.

\section{Results}

\section{General Information}

Of these 100 selected patients, 8 were excluded as they failed to meet the test protocol, and 92 patients were enrolled, consisting of 58 males and 34 females. Their average age was $58.9 \pm 10.3$ years and BMI $22.2 \pm 2.6$. Details of characteristics of patients enrolled can be found in Table 2 .

Table 2 Characteristics of Enrolled Patients $(n=92)$

\begin{tabular}{|l|l|}
\hline Patients' Characteristics & Value \\
\hline Age (years) & $58.9 \pm 10.3$ \\
Gender (male/female) & $58 / 34$ \\
BMI (kg/m²) & $22.2 \pm 2.6$ \\
ASA classification (grade I / II) & $9 / 83$ \\
\hline Medical comorbidities & \\
Hypertension (yes/no) & $31 / 61$ \\
Diabetes mellitus (yes/no) & $7 / 85$ \\
History of surgery (yes/no) & $32 / 60$ \\
\hline Occupation (worker/farmer/civil service/retirement/ & $37 / 13 / 6 / 21 /$ \\
other) & 15 \\
Education (college/middle school/primary school/ & $18 / 46 / 24 / 4$ \\
illiterate) & \\
\hline
\end{tabular}

Note: Data are expressed as the frequencies or mean $\pm S D$, as appropriate. Abbreviations: BMI, body mass index; ASA, American Society of Anesthesiologists.

\section{Surgery and Anaesthesia Information}

Of all 92 patients, the surgical time was $113.1 \pm 41.8 \mathrm{~min}$, volume of blood loss was $59.2 \pm 55.9 \mathrm{~mL}$, urine output was $231.7 \pm 185.1 \mathrm{~mL}$, infusion volume was $1117.9 \pm 341.1 \mathrm{~mL}$ and length of incision was $8.1 \pm 2.7 \mathrm{~cm}$. For dosages of intraoperative anaesthetics: sufentanil was 55.8 $\pm 9.4 \mu \mathrm{g}$, remifentanil was $741.4 \pm 321.5 \mu \mathrm{g}$, and propofol was $902.2 \pm 274.2 \mathrm{mg}$. The details of surgery and anaesthesia information of patients enrolled can be found in Table 3.

\section{Follow-Up of Postoperative Analgesia and Adverse Reactions}

The follow-up resting VAS pain scores of the 92 patients at $24 \mathrm{~h}, 48 \mathrm{~h}-72 \mathrm{~h}$ after operation were $2.3 \pm 1.2,2.0 \pm 0.9$ and $1.9 \pm 1.0$, respectively. The total amounts of sufentanil used were $34.7 \pm 10.5 \mu \mathrm{g}, 65.2 \pm 13.7 \mu \mathrm{g}$ and $94.7 \pm 11.6 \mu \mathrm{g}$, respectively (Table 3 ).

Within $72 \mathrm{~h}$ after surgery, the patients in each group had no sedation or respiratory depression. Forty-one patients had nausea with an incidence of $44.56 \%, 8$ patients had vomiting with an incidence rate of $8.69 \%, 3$ patients had pruritus with an incidence rate of $3.26 \%$ and 2 patients had hypotension with an incidence rate of $2.17 \%$.

Table 3 Surgery and Anaesthesia Data, Resting VAS Pain Score, Opioid Dosage, and Opioid-Related Adverse Events Within 72 h Post-Op $(n=92)$

\begin{tabular}{|l|l|}
\hline Item & Value \\
\hline Surgery and anaesthesia data & \\
Operation time $(\mathrm{min})$ & $113.1 \pm 41.8$ \\
Volume of blood loss $(\mathrm{mL})$ & $59.2 \pm 55.9$ \\
Infusion volume $(\mathrm{mL})$ & $1275.5 \pm 366.7$ \\
Urine output $(\mathrm{mL})$ & $231.7 \pm 185.1$ \\
Length of the incision $(\mathrm{cm})$ & $8.1 \pm 2.7$ \\
\hline Intraoperative anaesthetics & \\
Sufentanil $(\mu \mathrm{g})$ & $55.8 \pm 9.4$ \\
Remifentanil $(\mu \mathrm{g})$ & $741.4 \pm 321.5$ \\
Propofol (mg) & $902.2 \pm 274.2$ \\
\hline Resting VAS pain score & \\
24 h post-op & $2.3 \pm 1.2$ \\
$48 \mathrm{~h}$ post-op & $2.0 \pm 0.9$ \\
$72 \mathrm{~h}$ post-op & $1.9 \pm 1.0$ \\
\hline Sufentanil dosage $(\mu \mathrm{g})$ & \\
$24 \mathrm{~h}$ post-op & $34.7 \pm 10.5$ \\
$48 \mathrm{~h}$ post-op & $65.2 \pm 13.7$ \\
$72 \mathrm{~h}$ post-op & $94.7 \pm 11.6$ \\
\hline
\end{tabular}

Note: Data are expressed as the mean \pm SD.

Abbreviations: VAS, visual analogue scale; $24 \mathrm{~h}$ post-op, $24 \mathrm{~h}$ postoperation; 48 $\mathrm{h}$ post-op, $48 \mathrm{~h}$ postoperation; $72 \mathrm{~h}$ post-op, $72 \mathrm{~h}$ postoperation. 


\section{Preliminary Analysis of Genetic Polymorphisms of Cytokines on the Dosage of PCIA Sufentanil After Radical Lung Cancer Surgery}

The detection found that the variant frequencies of rs 1800795 and rs 1143634 were $100 \%$ and $0.5 \%$, respectively, which were similar to the variant frequencies in the East Asian population.

No significant difference was detected in the dosage of sufentanil at $72 \mathrm{~h}$ postoperative in many SNPs (ie, rs17561 C> A, rs1800587 G> A, rs16944 G> A, rs419598 T> C, rs4073 A> T, rs1800871 A> G, rs1800872 $\mathrm{T}>\mathrm{G}$,

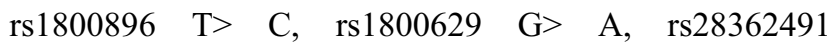
delATTG, rs3774932 A> G, rs842647 G>A, and rs8904 $\mathrm{G}>\mathrm{A})(\mathrm{p}>0.05)$. The dosage of sufentanil between different genotype groups of rs696 C> T $(p<0.05)$ was statistically significant at $72 \mathrm{~h}$ after operation, as shown in Table 4.

\section{The Rs696 Polymorphism Might Affect Postoperative Sufentanil Dosage for Analgesia in Patients After Radical Lung Cancer Surgery Rs696 Genotype and Allele Frequency Analysis}

The analysis showed that the variant frequency of the rs696 C> T allele in patients with lung cancer surgery was $35.3 \%$. The distribution of alleles and genotypes were in accordance with Hardy-Weinberg equilibrium $(\mathrm{p}>0.05)$. Patients were divided into wild-type homozygous (CC group), heterozygous (CT group) and homozygous (TT group) according to their genotypes. The rs696 C $>$ T genotype and allele frequencies are shown in Table 5.

\section{Analysis of the General Characteristics, Surgery and Anaesthesia Data, and Opioid-Related Adverse Events}

Patients were grouped according to the direct sequencing results of the rs696 C $>\mathrm{T}$ genotype. There was no significant difference in age, gender, BMI, ASA classification, medical comorbidities, occupation or education in each group $(\mathrm{p}>0.05)$ (Table 6). There was no statistically significant difference in the surgical time, volume of blood loss, infusion volume, urine volume, length of incision, or intraoperative dosages of sufentanil, remifentanil and propofol in each group $(\mathrm{p}>0.05)$ (Table 6).

Within $72 \mathrm{~h}$ postoperation, the patients in each group were followed-up without hypersedation or respiratory depression. There were no significant differences in nausea, vomiting, pruritus or hypotension in the three groups $(\mathrm{p}>0.05)$ (Table 6).

\section{Comparison of the Resting VAS Pain Scores and} PCIA Sufentanil Dosages Within 72 h of Each Group The resting VAS pain scores of the three groups were not significantly different $(\mathrm{p}>0.05)$ (Figure $1 \mathrm{~A})$. The dosages of PCIA sufentanil of three groups were not significantly different at $24 \mathrm{~h}$ postoperation ( $\mathrm{p}>0.05$ ) (Figure 1B). The dosage of PCIA sufentanil in the TT group was higher than that in the CC group and the CT group at 48-72 $\mathrm{h}$ postoperation $(\mathrm{p}<0.05)$ (Figure 1B). There was no significant difference in the dosage of PCIA sufentanil between the CC group and the CT group at 48-72 $\mathrm{h}$ postoperation $(\mathrm{p}>0.05)$ (Figure 1B).

\section{Discussion}

The present study aims to explore the effect of genetic polymorphisms of cytokines on the dosage of sufentanil for PCIA after radical lung cancer surgery. This study demonstrated that the dosage of PCIA sufentanil in the homozygous TT genotype of rs696 was higher than that in the wild-type homozygous CC and the heterozygous CT genotypes at $48-72 \mathrm{~h}$ postoperation, suggesting that the rs696 genetic polymorphism may cause individual differences in the analgesic effect of PCIA sufentanil after radical lung cancer surgery.

Postoperative pain is closely related to inflammatory cytokines. Inflammation gene polymorphisms have significant importance in modulating pain severity. ${ }^{28}$ We hypothesized that genetic polymorphisms of cytokines might affect the dosage of postoperative opioids. To this end, we wanted to explore whether or not the genetic polymorphisms of cytokines affect the dosage of PCIA sufentanil after radical lung cancer surgery. After reviewing the available studies, we found that IL-1A, ${ }^{24,29-31} \mathrm{IL}-1 \beta,{ }^{24,29,31,32} \mathrm{IL}-1 \mathrm{RN},{ }^{24,29,33}$ IL-6, ${ }^{24,29,34,35}$ CXCL8, ${ }^{24,29,35,36}$ IL-10, ${ }^{24,29}$ TNF, ${ }^{20,24,28}$ $\mathrm{NF \kappa B} 1,{ }^{24,29,37} \mathrm{REL}^{37}$ and NFKBIA ${ }^{24,37}$ are closely related to pain. After searching the NCBI SNP database (http://www. ncbi.nlm.nih.gov/sites/entrez?db=Snp) and inputting related genes, 16 related genetic polymorphism sites were selected with a variant frequency $>5 \%$. We did not find that these SNPs 
Table 4 Preliminary Analysis of the Effect of Genetic Polymorphisms of Cytokines on the Dosage of PCIA Sufentanil After Radical Lung Cancer Surgery

\begin{tabular}{|c|c|c|c|c|c|}
\hline SNP Site & Genotype & Quantity & p value ${ }^{a}$ & Sufentanil Dosage $(\mu \mathrm{g})$ & p value \\
\hline $\begin{array}{l}\text { IL-IA } \\
\quad r s|756|\end{array}$ & $\begin{array}{l}\mathrm{CC} \\
\mathrm{CA} \\
\mathrm{AA}\end{array}$ & $\begin{array}{l}79 \\
13 \\
0\end{array}$ & 0.77 & $\begin{array}{l}95.2 \pm 11.3 \\
90.6 \pm 11.3\end{array}$ & 0.179 \\
\hline rs 1800587 & $\begin{array}{l}\text { GG } \\
\text { GA } \\
\mathrm{AA}\end{array}$ & $\begin{array}{l}79 \\
13 \\
0\end{array}$ & 0.77 & $\begin{array}{l}95.2 \pm 11.3 \\
90.6 \pm 11.3\end{array}$ & 0.179 \\
\hline $\begin{array}{l}\text { IL-I } \beta \\
\quad r s \mid 6944\end{array}$ & $\begin{array}{l}\text { AA } \\
\text { GA } \\
\text { GG }\end{array}$ & $\begin{array}{l}17 \\
48 \\
27\end{array}$ & 0.87 & $\begin{array}{l}92.2 \pm 10.0 \\
96.1 \pm 12.0 \\
93.3 \pm 10.8\end{array}$ & 0.372 \\
\hline $\begin{array}{l}\text { IL-IRN } \\
\text { rs419598 }\end{array}$ & $\begin{array}{l}\text { TT } \\
\text { CT } \\
\text { CC }\end{array}$ & $\begin{array}{l}85 \\
7 \\
0\end{array}$ & 0.93 & $\begin{array}{l}94.5 \pm 11.5 \\
94.8 \pm 9.8\end{array}$ & 0.945 \\
\hline $\begin{array}{l}\text { CXCL8 } \\
\text { rs4073 }\end{array}$ & $\begin{array}{l}\text { AA } \\
\text { TA } \\
\text { TT }\end{array}$ & $\begin{array}{l}8 \\
44 \\
40\end{array}$ & 0.70 & $\begin{array}{l}95.6 \pm 9.0 \\
93.7 \pm 9.8 \\
95.2 \pm 13.2\end{array}$ & 0.802 \\
\hline $\begin{array}{l}\text { IL-I0 } \\
\quad \text { rs|80087I }\end{array}$ & $\begin{array}{l}\text { AA } \\
\text { GA } \\
\text { GG }\end{array}$ & $\begin{array}{l}45 \\
36 \\
11\end{array}$ & 0.67 & $\begin{array}{l}93.2 \pm 9.8 \\
96.5 \pm 13.7 \\
93.8 \pm 7.6\end{array}$ & 0.416 \\
\hline rs 1800872 & $\begin{array}{l}\text { TT } \\
\text { GT } \\
\text { GG }\end{array}$ & $\begin{array}{l}45 \\
36 \\
11\end{array}$ & 0.67 & $\begin{array}{l}93.2 \pm 9.8 \\
96.5 \pm 13.7 \\
93.8 \pm 7.6\end{array}$ & 0.416 \\
\hline rsl800896 & $\begin{array}{l}\mathrm{TT} \\
\mathrm{CT} \\
\mathrm{CC}\end{array}$ & $\begin{array}{l}74 \\
16 \\
2\end{array}$ & 0.62 & $\begin{array}{l}93.7 \pm 11.0 \\
99.4 \pm 12.3 \\
88.8 \pm 3.3\end{array}$ & 0.141 \\
\hline $\begin{array}{l}\text { TNF } \\
\text { rsI800629 }\end{array}$ & $\begin{array}{l}\text { GG } \\
\text { GA } \\
\text { AA }\end{array}$ & $\begin{array}{l}81 \\
11 \\
0\end{array}$ & 0.83 & $\begin{array}{l}94.6 \pm 11.5 \\
94.4 \pm 10.5\end{array}$ & 0.968 \\
\hline $\begin{array}{l}\text { NFKBI } \\
\quad r s 2836249 I\end{array}$ & $\begin{array}{l}\text { ins/ins } \\
\text { ins/del } \\
\text { del/del }\end{array}$ & $\begin{array}{l}74 \\
16 \\
2\end{array}$ & 0.62 & $\begin{array}{l}93.7 \pm 11.0 \\
99.4 \pm 12.3 \\
88.8 \pm 3.3\end{array}$ & 0.141 \\
\hline rs3774932 & $\begin{array}{l}\text { AA } \\
\text { GA } \\
\text { GG }\end{array}$ & $\begin{array}{l}32 \\
42 \\
18\end{array}$ & 0.82 & $\begin{array}{l}95.1 \pm 10.3 \\
95.6 \pm 10.0 \\
91.1 \pm 15.3\end{array}$ & 0.361 \\
\hline $\begin{array}{l}\text { REL } \\
\qquad \text { rs842647 }\end{array}$ & $\begin{array}{l}\text { GG } \\
\text { GA } \\
\text { AA }\end{array}$ & $\begin{array}{l}66 \\
25 \\
1\end{array}$ & 0.72 & $\begin{array}{l}95.4 \pm 12.1 \\
92.6 \pm 9.1 \\
86.4\end{array}$ & 0.456 \\
\hline
\end{tabular}

(Continued) 
Table 4 (Continued).

\begin{tabular}{|c|l|l|l|l|l|}
\hline SNP Site & Genotype & Quantity & p value $^{\mathbf{a}}$ & Sufentanil Dosage $(\mu \mathrm{g})$ & p value $^{\mathbf{b}}$ \\
\hline NFKBIA & & & & & \\
rs8904 & GG & 37 & 0.80 & $93.0 \pm 12.1$ & 0.052 \\
& GA & 45 & & $94.3 \pm 9.5$ & $103.0 \pm 15.6$ \\
\hline rs696 & AA & 10 & & $93.2 \pm 12.2$ & $0.025 *$ \\
& CC & 36 & 0.53 & $93.9 \pm 9.5$ & $104.6 \pm 15.6$ \\
& CT & 47 & & & \\
\hline
\end{tabular}

Notes: Data are expressed as the frequencies or mean \pm SD, as appropriate. $P$ value ${ }^{a}$ for Hardy-Weinberg analyses of different genotypes; $P$ value ${ }^{b}$ for PCIA sufentanil dosage of different genotypes; *The difference in the dosage of PCIA sufentanil between three groups was significant, $P<0.05$.

Abbreviations: SNP, single-nucleotide polymorphism; IL-IA, interleukin-IA; IL-I $\beta$, interleukin-I $\beta$; IL-IRN, interleukin-IRN; CXCL8, C-X-C motif chemokine ligand 8; IL-

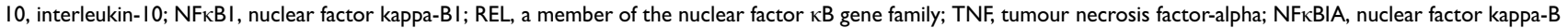
inhibitor alpha.

Table 5 NFkBIA Rs696 C> T Genotypes and Allele Frequency

\begin{tabular}{|l|l|l|l|l|l|l|l|}
\hline \multicolumn{9}{|l|}{ Allele } & C & T & Total & CC & CT & TT & Total \\
\hline & C & 65 & 184 & 36 & 47 & 9 & 92 \\
\hline Quantity & 119 & $35.33 \%$ & $100 \%$ & $39.13 \%$ & $51.09 \%$ & $9.78 \%$ & $100 \%$ \\
Frequency (\%) & $64.67 \%$ & &
\end{tabular}

(ie, rs17561 C> A, rs1800587 G>A, rs16944 G>A, rs419598 $\mathrm{T}>\mathrm{C}, \mathrm{rs} 1800629 \mathrm{G}>\mathrm{A}, \mathrm{rs} 28362491$ delATTG, rs3774932 A> $\mathrm{G}$, and rs842647 G> A) were associated with dosage of PCIA sufentanil, which may be related to factors such as ethnic differences and population conditions. However, we found for the first time that the NFאBIA rs696 genetic polymorphism might have an impact on the dosage of PCIA sufentanil after radical lung cancer surgery.

Rs696 is located in the 3 prime UTR variants of the NFאBIA gene. Studies have shown that the frequency of rs696 $\mathrm{C}>\mathrm{T}$ variants is related to differences in population and ethnicity. Americans have a variant frequency of $30 \%$ compared to Africans, who have a variant frequency of $65 \%$ and East Asians, who have a variant frequency of 39\% (https://www.ncbi. nlm.nih.gov/snp/rs696 \# frequency_ tab). In this study, the rs696 $\mathrm{C}>\mathrm{T}$ variant frequency of patients with lung cancer was $35.3 \%$, which was similar to that of the East Asian population, suggesting certain population representativeness.

NFкBIA genetic polymorphisms are related to a variety of inflammatory, autoimmune and tumour diseases. ${ }^{20,24,29,37}$ Many of the same inflammatory factors that promote tumour growth are also hypothesized to function as pain modulators. ${ }^{28}$ Reyes-Gibby et al, ${ }^{28}$ found that an additive model for NFKBIA Ex6+50 C>T (rs8904) was predictive of severe pain in lung cancer patients. However, no relevant study has been conducted to examine NFkBIA genetic polymorphism and dosages of postoperative opioids.

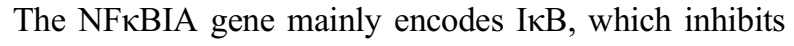
the NF- $\kappa \mathrm{B}$ signalling pathway under several physiological processes, such as by biasing NF- $\mathrm{B}$ nucleocytoplasmic dynamics and blocking its DNA binding. ${ }^{37,38}$ Inhibiting the $\mathrm{NF}-\kappa \mathrm{B}$ signalling pathway can effectively decrease levels of inflammatory cytokines and reduce the severity of pain. ${ }^{37,39,40}$ Zhao et al, ${ }^{41}$ found that the NFkBIA rs1957106 polymorphism is associated with lower mRNA and NFKBIA protein levels. We speculate that the homozygous TT genotype of rs696 might cause lower mRNA levels and protein expression of $\mathrm{I} \kappa \mathrm{B},{ }^{41}$ decreasing the inhibitory function of the $\mathrm{NF}-\kappa \mathrm{B}$ signalling pathway and increasing the levels of perioperative inflammatory cytokines, which leads to increased postoperative pain and opioid dosage. 
Table 6 Patients' Characteristics, Surgery and Anaesthesia Data, and Opioid-Related Adverse Events Based on the Different Genotypes of NFKBIA Rs696

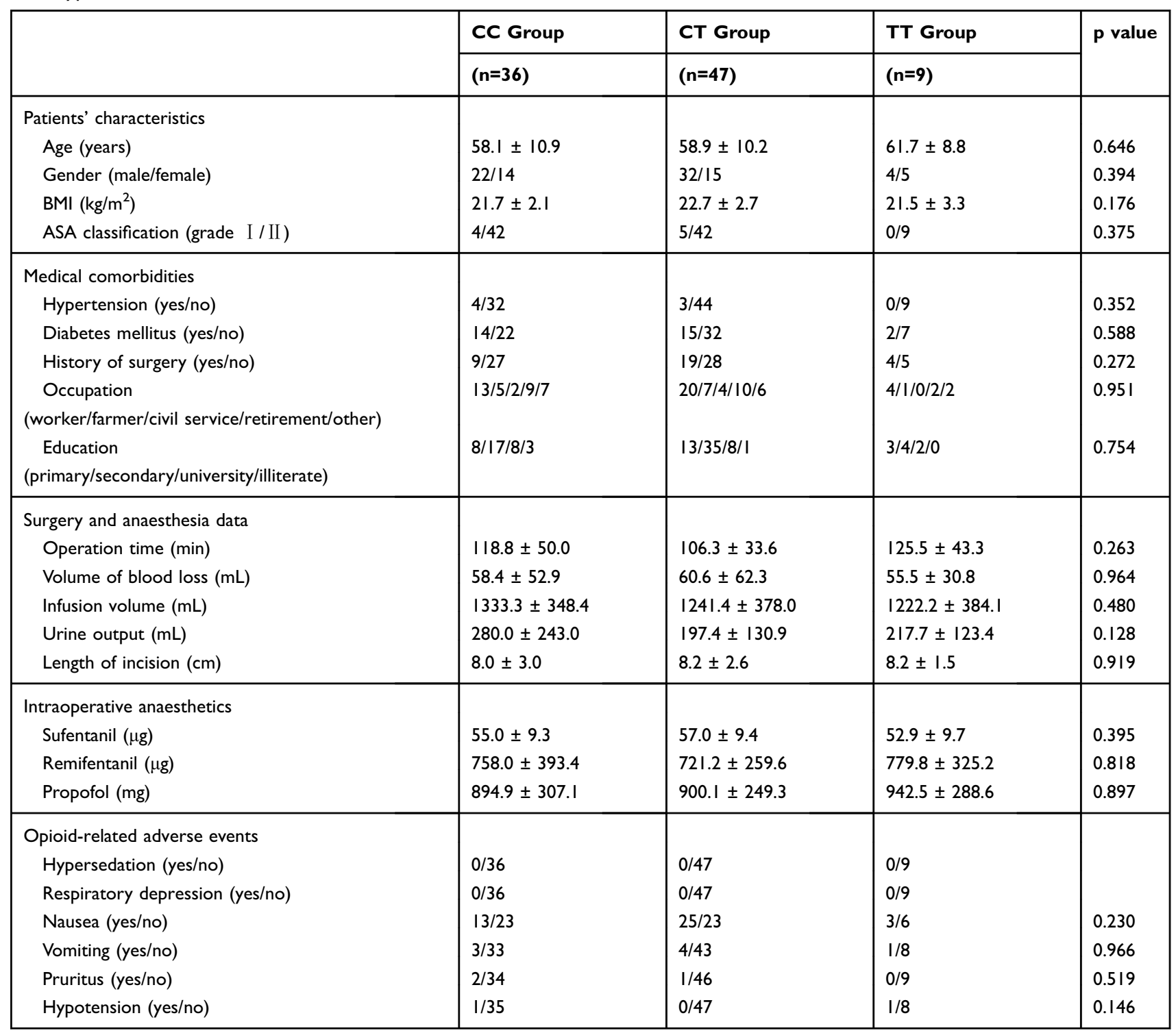

Note: Data are expressed as the frequencies or mean $\pm \mathrm{SD}$, as appropriate.

Abbreviations: CC group, the wild-type homozygotes of NFkBIA rs696 CC group; CT group, the heterozygotes of NFkBIA rs696 CT group; TT group, the homozygotes of NFKBIA rs696 TT group; BMI, body mass index; ASA, American Society of Anesthesiologists.

Our study has some limitations. First, the preoperative pain state and use of steroids have not been considered in this study, but they may play a big role in determining inflammation and pain perception, and indirectly, the need for opioids. Second, we did not examine the levels of the corresponding cytokines and their changes in the blood. Third, only partial gene fragments, not complete genes, were detected in this study. The differences in the selected gene fragments may have a certain effect on the results, while the selected gene segments were highly representative with a variant frequency $>5 \%$. Finally, the selected group of lung cancer patients in East Asia may have a certain effect on the results, and more studies might be needed to confirm our findings.

In summary, genetic polymorphisms of cytokines, specifically NFKBIA rs696, may be one of the individual genetic factors that causes a difference in the analgesic effect of PCIA sufentanil after radical lung cancer surgery. 

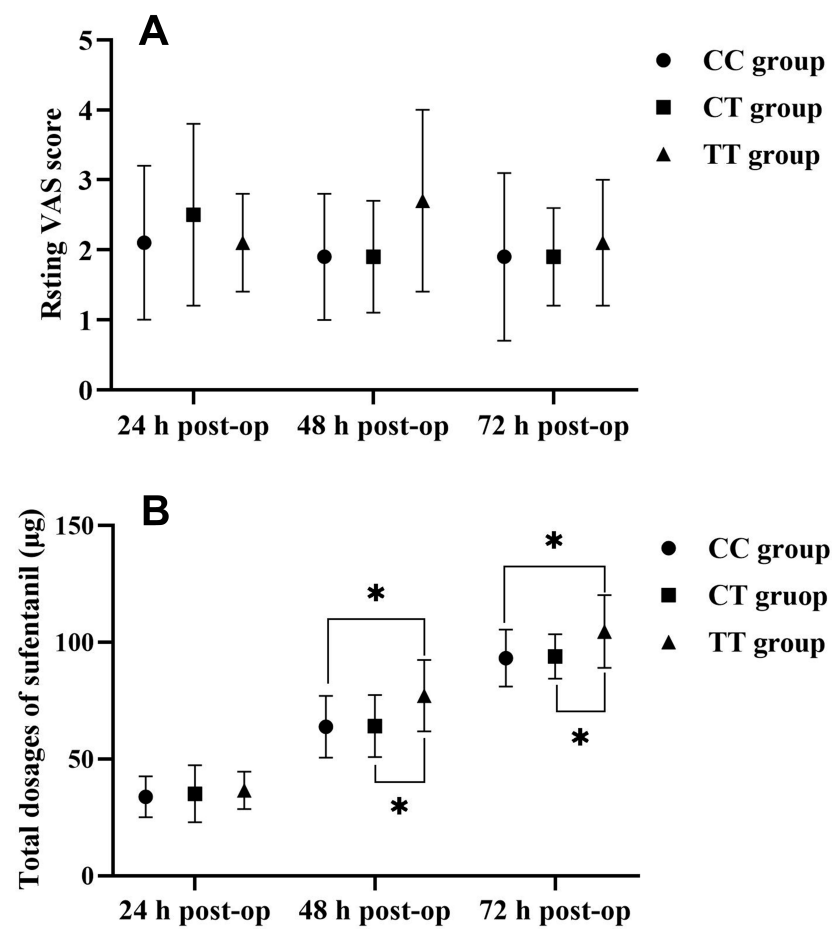

Figure I (A and B) Comparison of the resting VAS scores and PCIA sufentanil dosages within $72 \mathrm{~h}$ by the different genotypes of NFKBIA rs696. *The difference of the dosage of PCIA sufentanil between groups was significant, $P<0.05$. Abbreviations: CC group, the wild-type homozygotes of NFKBIA rs696 CC group; CT group, the heterozygotes of NFKBIA rs696 CT group; TT group, the homozygotes of NFKBIA rs696 TT group; VAS, visual analogue scale; $24 \mathrm{~h}$ post-op, 24 $\mathrm{h}$ postoperation; $48 \mathrm{~h}$ post-op, $48 \mathrm{~h}$ postoperation; $72 \mathrm{~h}$ post-op, $72 \mathrm{~h}$ postoperation.

\section{Disclosure}

Jian Guo and Fei Yuan are co-first authors. Mr Jian Guo reports grants from Medical and Health Science and Technology Plan of Zhejiang Province (WKJ-ZJ-2025), grants from General Scientific Research Project of the Zhejiang Provincial Department of Education (Y201839727), during the conduct of the study. The authors report no other conflicts of interest in this work.

\section{References}

1. Beverly A, Kaye AD, Ljungqvist O, Urman RD. Essential elements of multimodal analgesia in enhanced recovery after surgery (ERAS) guidelines. Anesthesiol Clin. 2017;35(2):e115-e143. doi:10.1016/j. anclin.2017.01.018

2. Costantini R, Affaitati G, Fabrizio A, Giamberardino MA. Controlling pain in the post-operative setting. Int J Clin Pharmacol Ther. 2011;49 (2):116-127. doi:10.5414/cp201401

3. Niraj G, Kelkar A, Kaushik V, et al. Audit of postoperative pain management after open thoracotomy and the incidence of chronic postthoracotomy pain in more than 500 patients at a tertiary center. J Clin Anesth. 2017;36:174-177. doi:10.1016/j.jclinane.2016.10.011

4. Chou R, Gordon DB, de Leon-casasola OA, et al. Management of postoperative pain: a clinical practice guideline from the American pain society, the american society of regional anesthesia and pain medicine, and the American society of anesthesiologists' committee on regional anesthesia, executive committee, and administrative council. $J$ Pain. 2016;17(2):131-157. doi:10.1016/j.jpain.2015.12.008
5. Dong CS, Zhang J, Lu Q, et al. Effect of dexmedetomidine combined with sufentanil for post- thoracotomy intravenous analgesia: a randomized, controlled clinical study. BMC Anesthesiol. 2017;17 (1):33. doi:10.1186/s12871-017-0324-4

6. van de Donk T, Ward S, Langford R, Dahan A. Pharmacokinetics and pharmacodynamics of sublingual sufentanil for postoperative pain management. Anaesthesia. 2018;73(2):231-237. doi:10.1111/anae.14132

7. Frampton JE. Sublingual sufentanil: a review in acute postoperative pain. Drugs. 2016;76(6):719-729. doi:10.1007/s40265-016-0571-6

8. Minkowitz HS. A review of sufentanil and the sufentanil sublingual tablet system for acute moderate to severe pain. Pain Manag. 2015;5 (4):237-250. doi:10.2217/pmt.15.22

9. Smith DM, Weitzel KW, Cavallari LH, Elsey AR, Schmidt SO. Clinical application of pharmacogenetics in pain management. Per Med. 2018;15(2):117-126. doi:10.2217/pme-2017-0032

10. Packiasabapathy S, Horn N, Sadhasivam S. Genetics of perioperative pain management. Curr Opin Anaesthesiol. 2018;31(6):749-755. doi:10.1097/aco.0000000000000660

11. Kuip EJ, Zandvliet ML, Koolen SL, Mathijssen RH, van der Rijt CC. A review of factors explaining variability in fentanyl pharmacokinetics; focus on implications for cancer patients. $\mathrm{Br} J$ Clin Pharmacol. 2017;83(2):294-313. doi:10.1111/bcp.13129

12. Lee MG, Kim HJ, Lee KH, Choi YS. The influence of genotype polymorphism on morphine analgesic effect for postoperative pain in children. Korean J Pain. 2016;29(1):34-39. doi:10.3344/kjp.2016.29.1.34

13. Hajj A, Peoc'h K, Laplanche JL, et al. Genotyping test with clinical factors: better management of acute postoperative pain? Int $J \mathrm{Mol}$ Sci. 2015;16(3):6298-6311. doi:10.3390/ijms16036298

14. Kosarac B, Fox AA, Collard CD. Effect of genetic factors on opioid action. Curr Opin Anaesthesiol. 2009;22(4):476-482. doi:10.1097/ ACO.0b013e32832e 34c9

15. Yoshida K, Nishizawa D, Ide S, Ichinohe T, Fukuda KI, Ikeda K. A pharmacogenetics approach to pain management. Neuropsyc hopharmacol Rep. 2018;38(1):2-8. doi:10.1002/npr2.12003

16. Peiro AM. Pharmacogenetics in pain treatment. Adv Pharmacol. 2018;83:247-273. doi:10.1016/bs.apha.2018.04.004

17. Zhang F, Tong J, Hu J, et al. COMT gene haplotypes are closely associated with postoperative fentanyl dose in patients. Anesth Analg. 2015;120(4):933-940. doi:10.1213/ane.0000000000000563

18. Yuan JJ, Hou JK, Zhang W, et al. CYP3A4 * $1 \mathrm{G}$ genetic polymorphism influences metabolism of fentanyl in human liver microsomes in Chinese patients. Pharmacology. 2015;96(1-2):55-60. doi:10.1159/ 000433441

19. Jones RO, Anderson NH, Murchison JT, et al. Innate immune responses after resection for lung cancer via video-assisted thoracoscopic surgery and thoracotomy. Innovations. 2014;9(2):93-103; discussion 103. doi:10.1097/imi.0000000000000061

20. Ko FC, Rubenstein WJ, Lee EJ, Siu AL, Sean Morrison R. TNF-alpha and sTNF-RII are associated with pain following hip fracture surgery in older adults. Pain Med. 2018;19(1):169-177. doi:10.1093/pm/pnx085

21. Si HB, Yang TM, Zeng Y, et al. Correlations between inflammatory cytokines, muscle damage markers and acute postoperative pain following primary total knee arthroplasty. BMC Musculoskelet Disord. 2017;18(1):265. doi:10.1186/s12891-017-1597-y

22. Langkilde A, Jakobsen TL, Bandholm TQ, et al. Inflammation and post-operative recovery in patients undergoing total knee arthroplasty-secondary analysis of a randomized controlled trial. Osteoarthritis Cartilage. 2017;25(8):1265-1273. doi:10.1016/j. joca.2017.03.008

23. Watkins LR, Milligan ED, Maier SF. Glial activation: a driving force for pathological pain. Trends Neurosci. 2001;24(8):450-455. doi:10.1016/s0166-2236(00)01854-3

24. Stephens KE, Levine JD, Aouizerat BE, et al. Associations between genetic and epigenetic variations in cytokine genes and mild persistent breast pain in women following breast cancer surgery. Cytokine. 2017;99:203-213. doi:10.1016/j.cyto.2017.07.006 
25. Ji RR, Nackley A, Huh Y, Terrando N, Maixner W. Neuroinflammation and central sensitization in chronic and widespread pain. Anesthesiology. 2018;129(2):343-366. doi:10.1097/ aln.0000000000002130

26. Knotkova H, Fine PG, Portenoy RK. Opioid rotation: the science and the limitations of the equianalgesic dose table. J Pain Symptom Manage. 2009;38(3):426-439. doi:10.1016/j.jpainsymman.2009.06.001

27. Liu QY, Yu JT, Miao D, et al. An exploratory study on STX6, MOBP, MAPT, and EIF2AK3 and late-onset Alzheimer's disease. Neurobiol Aging. 2013;34(5):1519.e1513-1517. doi:10.1016/j.neurobiolaging. 2012.10.004

28. Reyes-Gibby CC, Spitz MR, Yennurajalingam S, et al. Role of inflammation gene polymorphisms on pain severity in lung cancer patients. Cancer Epidemiol Biomarkers Prev. 2009;18 (10):2636-2642. doi:10.1158/1055-9965.Epi-09-0426

29. Stephens K, Cooper BA, West C, et al. Associations between cytokine gene variations and severe persistent breast pain in women following breast cancer surgery. J Pain. 2014;15(2):169-180. doi:10.1016/j.jpain.2013.09.015

30. Schistad EI, Jacobsen LM, Roe C, Gjerstad J. The interleukin-1alpha gene $\mathrm{C}>\mathrm{T}$ polymorphism rs 1800587 is associated with increased pain intensity and decreased pressure pain thresholds in patients with lumbar radicular pain. Clin J Pain. 2014;30(10):869-874. doi:10.1097/ajp.0000000000000048

31. Oliveira A, Dinis-Oliveira RJ, Nogueira A, et al. Interleukin-1beta genotype and circulating levels in cancer patients: metastatic status and pain perception. Clin Biochem. 2014;47(13-14):1209-1213. doi:10.1016/j.clinbiochem.2014.04.009

32. Yilmaz IA, Ozge A, Erdal ME, Edgunlu TG, Cakmak SE, Yalin OO. Cytokine polymorphism in patients with migraine: some suggestive clues of migraine and inflammation. Pain Med. 2010;11(4):492-497. doi:10.1111/j.1526-4637.2009.00791.x
33. Bjorland S, Moen A, Schistad E, Gjerstad J, Roe C. Genes associated with persistent lumbar radicular pain; a systematic review. BMC Musculoskelet Disord. 2016;17(1):500. doi:10.1186/s12891-016-1356-5

34. Kovacs D, Eszlari N, Petschner P, et al. Interleukin-6 promoter polymorphism interacts with pain and life stress influencing depression phenotypes. J Neural Transm. 2016;123(5):541-548. doi:10.1007/s00702-016-1506-9

35. Svetlik S, Hronova K, Bakhouche H, Matouskova O, Slanar O. Pharmacogenetics of chronic pain and its treatment. Mediators Inflamm. 2013;2013:864319. doi:10.1155/2013/864319

36. Slade GD, Conrad MS, Diatchenko L, et al. Cytokine biomarkers and chronic pain: association of genes, transcription, and circulating proteins with temporomandibular disorders and widespread palpation tenderness. Pain. 2011;152(12):2802-2812. doi:10.1016/j.pain

37. Zhang Q, Lenardo MJ, Baltimore D. 30 years of NF-kappaB: a blossoming of relevance to human pathobiology. Cell. 2017;168 (1-2):37-57. doi:10.1016/j.cell.2016.12.012

38. Mulero MC, Huxford T, Ghosh G, kappaB NF. IkappaB, and IKK: integral components of immune system signaling. Adv Exp Med Biol. 2019;1172:207-226. doi:10.1007/978-981-13-9367-9_10

39. Xiang $\mathrm{HC}$, Lin $\mathrm{LX}, \mathrm{Hu} \mathrm{XF}$, et al. AMPK activation attenuates inflammatory pain through inhibiting NF-kappaB activation and IL-1beta expression. $J$ Neuroinflammation. 2019;16(1):34. doi:10.1186/s12974-019-1411-x

40. Chen X, Zhang B, Li J, et al. Celastrol attenuates incision-induced inflammation and pain associated with inhibition of the NF-kappaB signalling pathway via SARM. Life Sci. 2018;205:136-144. doi:10.1016/j.lfs.2018.05.020

41. Zhao Z, Zhong X, Wu T, et al. Identification of a NFKBIA polymorphism associated with lower NFKBIA protein levels and poor survival outcomes in patients with glioblastoma multiforme. Int J Mol Med. 2014;34(5):1233-1240. doi:10.3892/ijmm.2014.1932
Journal of Pain Research

\section{Publish your work in this journal}

The Journal of Pain Research is an international, peer reviewed, open access, online journal that welcomes laboratory and clinical findings in the fields of pain research and the prevention and management of pain. Original research, reviews, symposium reports, hypothesis formation and commentaries are all considered for publication. The manuscript management system is completely online and includes a very quick and fair peer-review system, which is all easy to use. Visit http:// www.dovepress.com/testimonials.php to read real quotes from published authors. 